Published in final edited form as:

Toxicol Pathol. 2012 ; 40(2): 166-173. doi:10.1177/0192623311428477.

\title{
Cellular Regulation of the Inflammatory Response
}

\author{
William J. Janssen and Peter M. Henson \\ Departments of Medicine, Pediatrics and Immunology, National Jewish Health and University of \\ Colorado, Denver, Colorado, USA
}

\begin{abstract}
In simple terms, inflammation can be defined as a beneficial, nonspecific response of tissues to injury that generally leads to restoration of normal structure and function. In this concept, resolution of the inflammatory response, once it has achieved its protective and pro-immunogenic functions, becomes a critical determinant of what might be considered the paradox of inflammation. On one hand, inflammation is essential to resolve tissue injury and maintain homeostasis. On the other, inflammation is a key participant in the great majority of human diseases. Accordingly, to achieve complete resolution of inflammation, it is necessary to both turn off inflammatory mediator production and inflammatory cell accumulation and to remove inflammatory cells and debris without initiating an autoimmune response. Much of this process involves key activities of the mononuclear phagocyte series of cells, including resident and recruited macrophages. Recognition of activated and dying acute inflammatory cells by mononuclear phagocytes has been shown to (a) enhance macropinocytic activity for removal of debris, (b) enhance uptake of the effete inflammatory cells themselves, (c) induce inflammosuppressive and immunosuppressive mediators such as TGF $\beta$ and IL-10 that can downregulate and limit proinflammatory mediator production, and (d) induce production of growth factors for tissue cells that may play key roles in tissue repair. Defects in these highly regulated processes are associated with persistent inflammation and/or autoimmunity in overaggressive resolution mechanisms such as nonresolving fibrosis or persistent tissue destruction as in emphysema.
\end{abstract}

\section{Keywords}

Inflammation; apoptosis; phagocytosis; macropinocytosis; macrophage

\section{Introduction}

Resurging interest in inflammation, for example as participating in obesity, cardiovascular disease, or cancer, has led to a focus on the cytokines, chemokines, and other inflammatory mediators that orchestrate the process (Libby 2002; Nathan 2002; Tracey 2007; Hotamisligil

\footnotetext{
Copyright $@ 2012$ by the Author(s)

Address correspondence to: Dr. William J. Janssen, National Jewish Health, 1400 Jackson St., Denver, CO 80206, USA; janssenw@njhealth.org.

The author(s) declared no potential conflicts of interest with respect to the authorship and/or publication of this article.

For reprints and permissions queries, please visit SAGE's Web site at http://www.sagepub.com/journalsPermissions.nav.
} 
2006) to an extent that often downplays the critical role played by the cells that both induce and respond to these mediators. Thus, we argue that while a cytokine theory of disease is important to recognize, the balance between the cellular and humoral elements should always be kept in mind: an interesting recapitulation of similar arguments in the concepts of immunity that were prevalent a century ago (Mechnikov 1908). Likewise, the term regulation is all too often unclear since it could imply either an enhancing or inhibitory function or, as is often the case, a vague and uncharacterized double meaning. Here we will focus on the role of cells in suppressing the inflammatory response, leading to its normal resolution; as in the words of the eighteenth-century Scottish physician, William Cullen, "If an inflammation is to be cured while the state and texture of the part remain entire, the disease is said to be terminated by Resolution." A rationale for this perspective is that an understanding of normal resolution in a protective and self-limited inflammatory response can provide insight into, and eventual therapeutic interventional opportunities toward, the persistent inflammatory processes that contribute to so many human diseases. A brief consideration of these processes, and especially their consequences, will therefore be the subject of this article. Rather than providing a comprehensive review (for which, see Serhan and Savill 2005; Barton 2008; Han and Ulevitch 2005; Luster, Alon, and von Andrian 2005), we will alternatively raise a few general points and, more importantly, identify areas needing more intensive investigation. Additionally, given our own areas of interest, the focus will be on processes and diseases of the respiratory tract. However, we suggest that while there clearly will be important tissue-specific elements to inflammation and its resolution, the concepts discussed herein will have broad applicability to resolution of inflammation of other organ systems and sites.

\section{Resolution of Inflammation}

As a response of the naïve tissue to insult, pro-inflammatory mediators are produced either from endogenous leukocytes (macrophages, monocytes, dendritic cells, or lymphocytes) and/or from the tissue cells themselves. These mediators are the key orchestrators of the inflammatory response, initiating recruitment of neutrophils and later monocytes and lymphocytes to areas of injury and inducing the systemic responses well known to accompany classical inflammation (e.g., changes in blood flow and temperature). However, pro-inflammatory mediator production in the self-limited response is soon turned off, in part presumably due to cessation of the initial stimulus consequent on the protective functions of the inflammatory response itself_-namely, removal of the invading pathogen (PAMPs), removal of the damaged tissue (DAMPs), and so on. In addition, a wave of antiinflammatory mediators occurs later in the response. Removal of any tissue debris, and in particular of the recruited inflammatory leukocytes, accompanies this inflammosuppressive effect and is in fact one of the mechanisms for its induction.

\section{Removal of Neutrophils as a Paradigm for Clearance of Inflammatory Cells}

In an acute, self-limited inflammatory reaction (Figure 1), recruited neutrophils are quickly cleared from the lesion as they undergo programmed cell death (PCD), often generalized as "apoptosis" (though strictly speaking, apoptosis represents but a subset of a number of forms of PCD; Kroemer et al. 2009; Fink and Cookson 2005; Okada and Mak 2004). Recognition 
of these apoptotic cells by phagocytes leads not only to their engulfment and rapid digestion but also to a host of additional responses that are involved in the overall resolution (see the following). Uptake of apoptotic neutrophils in vivo is highly efficient, to the degree that detection of dying neutrophils in injured tissues is normally difficult (Scott et al. 2001; Matute-Bello et al. 1997), even during the clearance phase of acute neutrophilic inflammation, as, for example, in bacterial pneumonia (Dockrell et al. 2001, 2003). Accordingly, we have suggested that histologic detection of apoptotic neutrophils should trigger consideration of either a massive wave of apoptosis and/or a defect in the clearance mechanisms (see the following).

The primary cells involved in apoptotic cell clearance are macrophages, although dendritic cells are also important players and may thereby contribute to either immunosuppressive or autoimmune sequelae. In addition, it has also become apparent that tissue cells such as endothelial cells, fibroblasts, and epithelial cells can also have, or develop, the ability to recognize and ingest apoptotic cells (Aguilar et al. 1994; Monks et al. 2005; Petrovski et al. 2011; Suzuki, Takeda, and Farbman 1996; Svensson et al. 1999; Vandivier et al. 2009). The recognition and uptake mechanisms for apoptotic cells are highly evolutionarily conserved and differ from more classical types of phagocytosis (as mediated by antibody or complement) in both physical uptake mechanisms and intracellular signaling pathways. As such, we have given this unique form of phagocytosis the name efferocytosis (from effero; to carry to the grave; to bury; deCathelineau and Henson 2003).

Ligands on cells undergoing PCD and the receptors that recognize them are many-the processes appear to be highly redundant (see Table 1 and Gardai et al. 2006; Grimsley and Ravichandran 2003; Savill et al. 2002; Savill, Gregory, and Haslett 2003). Of the ligands expressed by apoptotic cells, phosphatidylserine (PS) carries particular importance. PS is normally confined to the inner cell membrane, but is rapidly exposed on the cell surface during early apoptosis. Many direct receptors for PS have been identified, as well as a number of soluble molecules that can tether PS to phagocyte surface receptors and act as "bridge molecules" or opsonins (Bratton and Henson 2008). Here for simplicity we will group these together as "PS recognition structures" or PSRS. Intriguingly, activated neutrophils, as well as other leukocytes, may also expose PS on their cell surfaces when they become activated, though in this case the exposure is transient rather than permanent as in apoptosis. Nonetheless, it has become apparent that such transient PS exposure may itself be enough to trigger some recognition and removal before the cells actually die (Marguet et al. 1999; Callahan, Williamson, and Schlegel 2000; Frasch et al. 2008).

Another general ligand that becomes exposed and/or altered on apoptotic cells is calreticulin, a protein normally found in the endoplasmic reticulum. A critical receptor for calreticulin is LDL receptor related protein-1 (LRP-1). The collectin family of pattern recognition molecules (e.g., mannose binding lectin, surfactant proteins A and D, C1q, and other related proteins) also recognizes surface changes on apoptotic cells (Palaniyar et al. 2004; Palaniyar, Nadesalingam, and Reid 2003; Jensen et al. 2007) and can act through LRP-1. 


\section{Macropinocytosis and Removal of Debris}

The process of efferocytosis appears to be a modified form of macropinocytosis that is dependent on the low molecular weight, Rho-family GTPase, Rac. Uptake of the apoptotic cell is accompanied by simultaneous ingestion of surrounding fluid (deCathelineau and Henson 2003; Bratton and Henson 2008), and in fact, the soluble "bridge molecules" mentioned previously can themselves enhance macropinocytosis (Hoffmann et al. 2001; Somersan and Bhardwaj). This then may contribute importantly to the clearance of debris, fluid phase constituents, and other leftovers from the inflammatory response. Intriguingly, some of the collectin family members, including the Ficolins, are able to recognize DNA and chromatin (Palaniyar et al. 2004; Palaniyar, Nadesalingam, and Reid 2003; Jensen et al. 2007), thereby providing a mechanism for removal of these classes of cell debris, including perhaps the neutrophil extracellular NETS that may have been generated in the course of the protective stages of the inflammatory process (see the article in this symposium by McDonald et al.).

\section{What Happens to the Macrophages?}

True resolution of inflammation requires subsequent removal of the macrophages. Mechanisms for this may be tissue specific, although in a fundamental sense the two main modes of macrophage removal include excretion from the body or apoptosis and their own subsequent efferocytosis. In the lung, some of the inflammatory macrophages may exit the body via the mucociliary escalator to be coughed up and swallowed. However, clear evidence of apoptosis and local removal exists (Janssen et al. 2011), and we suggest that this is the dominant fate of macrophages in the lungs, and perhaps at other inflammatory sites in the body as well. In the peritoneum, migration of macrophages to the local lymph nodes has been reported (Cao et al. 2005; Bellingan et al. 1996, 2002). Even in this case, the eventual fate of the macrophage is still likely apoptosis and ingestion since there is no evidence for necrotic death or excretion of macrophages from the blood stream or lymphatics into the lungs or GI tract for external disposal.

\section{Inflammosuppressive and Immunosuppressive Consequences of Apoptotic Cell Recognition}

The previous comments emphasize the importance of clearing cells and debris produced as inevitable consequences of the inflammatory response in order to allow injured tissues to recover and return to normal structure and function. However, inflammation itself also has to be halted for resolution to occur. In other words, following correction of the initiating event (i.e., removal of pathogens), the production of proinflammatory chemokines and cytokines needs to be turned off. The protective functions of inflammation may be assumed to contribute to the first of these steps by removing the stimulus, thereby decreasing its induction of pro-inflammatory mediators. However, it has also become apparent that recognition of apoptotic inflammatory cells by phagocytes not only results in apoptotic cell removal, but also actively induces the generation of anti-inflammatory (inflammosuppressive) mediators, such as TGF $\beta$ and IL-10, and a spectrum of lipid mediators with anti-inflammatory properties (Fadok et al. 1998; Freire-de-Lima et al. 2006). 
In other words, removal of apoptotic cells is generally actively inflammosuppressive, and in fact is also able to actively suppress the innate and adaptive immune response (Savill et al. 2002; Huynh, Fadok, and Henson 2002; Savill 1997). The pathways primarily responsible for these resolution-inducing effects appear to involve the recognition of phosphatidylserine on apoptotic cells, although the precise set of receptors and/or bridge molecules that mediate these effects is not entirely clear. Likely candidates include the TAM family of receptor tyrosine kinases, whose PS-recognizing bridge molecule ligands are GAS6 and Protein S (Scott et al. 2001; Ishimoto et al. 2000); however, it is likely that other receptors are also involved.

Many of the inflammosuppressive and immunosuppressive effects of efferocytosis appear to result from the aforementioned induction of anti-inflammatory mediators, such as TGF $\beta$. However, a number of studies also suggest that efferocytosis turns off production of proinflammatory mediators, for example by blockade of the $\mathrm{NF} \kappa \mathrm{B}$ pathways (Amarilyo et al. 2010; Cvetanovic and Ucker 2004). Likely relevant to these processes is the treatment regimen termed extracorporeal photopheresis (ECP) that has been proposed as a therapeutic strategy for patients with chronic inflammatory diseases (Babic 2008; Chiesa-Fuxench and Gonzalea-Chavez 2010; Szodoray et al. 2010). In this method, leukocytes are removed from the patient, treated ex vivo with the light-sensitive dye psoralen and light, and then reinfused. One can reasonably infer that these cells undergo apoptosis, providing a source of PS-exposing cells, that when recognized and ingested by phagocytes induce immunosuppression. However, it is also important to note that a number of studies have also suggested pro-inflammatory effects deriving from the presence of apoptotic cells (as well as pro-immunogenic consequences of apoptotic cell ingestion). A number of explanations for this dichotomy include the presence on apoptotic cells of ligands that, unlike PS, are potentially pro-inflammatory (Peter et al. 2010). In this context, it is important to note that the processes involved represent a delicate balance between pro-inflammatory effects of dying cells, especially when they undergo secondary necrosis, versus the strong antiinflammatory effect seen normally during resolution of acute inflammatory events. To no surprise (as noted in the following), defects in apoptotic cell recognition and removal and/or changes in this balance can contribute to persistent inflammation and autoimmunity.

\section{Regenerative Consequences of Apoptotic Cell Recognition}

Although less well studied for the signaling pathways involved, apoptotic cell recognition can also induce macrophages to synthesize and secrete growth-maintenance factors (e.g., VEGF and HGF; Golpon et al. 2004; Morimoto et al. 2001), which exert potent effects on parenchymal tissue cells such as endothelial cells and epithelial cells (see Fig. 2). This raises the general concept that cell removal can lead to restoration of tissue cells, to maintain the homeostatic balance. We believe that this may be a more extensive story than has yet been defined and is well worth further investigation.

As noted earlier, one of the anti-inflammatory and anti-immunogenic molecules induced by recognition of apoptotic cells is TGF $\beta$. Since this multi-potent mediator also plays an important role in fibrotic processes, it too represents a two-edged sword in the broad question of inflammation resolution. An intriguing study of apoptotic cell contribution to 
lung injury and repair demonstrated that blockade of apoptosis early led to increased severity and death, whereas blockade later in the process led to decrease in fibroproliferative sequelae (Douglas et al. 2006). This supports the active role played by apoptosis (presumably of the inflammatory cells) in both resolution and potentially later in generation of fibrosis in circumstances when complete restoration of tissue structure cannot be achieved. The source of fibroblasts and myofibroblasts for such "abnormal" reparative process is not clear, but differentiation of fibroblasts and epithelial-mesenchymal transition (EMT) are both candidates and are both driven by TGF $\beta$. It is also worth noting that fibroblast and myofibroblast accumulation/development are normal processes of wound healing in other tissues, such as the skin. Here this fibrotic response can, for the most part, resolve later to restore normal function, though in other tissues functional impairment is all too often the consequence.

\section{Consequences of Defective or Inefficient Inflammatory Cell Removal}

Not surprisingly for such an important and highly regulated set of processes, defective and/or imbalanced responses to apoptotic cells can lead to a variety of pathologic responses. As such, defects in apoptotic cell clearance are beginning to be recognized as participants in a multitude of diseases. Here we will mention two such examples.

Systemic defects in apoptotic clearance mechanisms have been widely demonstrated in autoimmune diseases, such as systemic lupus erythematosus (Ren et al. 2003; Gaipl et al. 2005, 2007; Baumann et al. 2002; Herrmann et al. 1998) where increased numbers of apoptotic cells can be detected in the circulation (Ren et al. 2003; Courtney et al. 1999). Similar findings have been reported in mice prone to autoimmunity (Scott et al. 2001; Hanayama et al. 2004; Kim et al. 2003; Ling, Pi, and Holoshitz 2007; Botto et al. 1998; Heidari et al. 2006). These observations have led to the concept that secondary necrosis of dying cells may release intracellular constituents to the immune system as a critical source of autoantigens. Clearly, this would only be a small part of the overall story of autoimmunity and there are many other changes in the broader aspects of the immune system that also participate in the pathogenesis. However, in the light of increasing evidence of apoptotic cell recognition leading to elements of immunosuppression, one might speculate that defects in apoptotic cell clearance may contribute more to the autoimmune process than merely a supply of potential antigen.

Chronic obstructive pulmonary disease (COPD), which is characterized by severe changes to the airways (chronic bronchitis) and permanent loss of alveoli (emphysema), is another example of a disease that may be associated with defective recognition and removal of apoptotic and damaged cells. Once again, the starting point for such a concept was the detection of apoptotic cells within the parenchyma of the lungs from COPD patients (Kasahara et al. 2001). As noted earlier, such detection immediately raises the likelihood of significant ongoing cell death and especially, given the normal efficiency with which such cells are removed, of an accompanying defect of the clearance processes. Such a defect in apoptotic cell removal has been shown (Hodge et al. 2003, 2006, 2005, 2007; Morimoto, Janssen, Fessler, McPhillips, et al. 2006; Morimoto, Janssen, Fesser, Xiao, et al. 2006; Richens et al. 2009). The major etiologic agent for COPD is cigarette smoke, which both 
injures the lungs and induces persistent inflammation. However, only a proportion of smokers in fact develop the disease. This leads to the suspicion that one contributory element to disease development might indeed be an underlying propensity for inefficient apoptotic cell clearance, a concept that is supported by finding that blood monocytes matured into macrophages in vitro still show a defect in apoptotic cell uptake if taken from patients with COPD (R. W. Vandivier, unpublished data). Intriguingly, both inflammation and the presence of apoptotic cells have been shown to persist years after the patient has stopped smoking, leading investigators to propose a secondary and self-sustaining process in the lungs, probably autoimmune in nature (Lee et al. 2007; Aoshiba and Nagai 2009; Curtis, Freeman, and Hogg 2007; Taraseviciene-Stewart et al. 2006). Once again, the defective apoptotic cell recognition and uptake can be shown in patients after smoking cessation (Hodge et al. 2005), supporting the presence of an intrinsic defect and a possible link to autoimmunity.

Since the capacity for apoptotic cell uptake by phagocytes is programmable, deficiencies in this capacity may be induced by the local environment or may arise from intrinsic genetic or epigenetic factors. Studies of genetic polymorphisms in phagocytic receptors or uptake mechanisms are in their infancy but provide fertile areas for investigation. In addition, it has become apparent that a variety of stimuli can exogenously reduce macrophage efferocytic capacity. Thus, macrophages "programmed" toward a more inflammatory state (in murine systems sometimes termed $M I$ polarization) are less efficient at efferocytosis compared with cells programmed toward a reparative state, the latter showing up-regulation of receptors associated with apoptotic cell recognition (Gordon and Martinez 2010; Varin et al. 2010). In addition, stimulation of the phagocytes to increase the ratio of Rho:Rac activation (Rho is inhibitory) can induce immediate suppression of apoptotic cell uptake (Erwig et al. 1999; Tosello-Trampont, Nakada-Tsukui, and Ravichandran 2003), and if the imbalance is more persistent, could contribute to some of the effects seen, for example in COPD or other chronic inflammatory states. This latter effect may in some circumstances be mitigated by inhibitors of Rho kinase as a key downstream mediator of the Rho effect (Morimoto, Janssen, Fessler, McPhillips, et al. 2006; Richens et al. 2009; Janssen et al. 2008). This has led to suggestions for using statins (HMG-CoA reductase inhibitors) for enhancing apoptotic cell clearance via their effect on Rho activation through preventing its prenylation (Morimoto, Janssen, Fessler, McPhillips, et al. 2006; Morimoto, Janssen, Fessler, Xiao, et al. 2006; Gordon and Martinez 2010; Varin et al. 2010; Vandivier, Henson, and Douglas 2006).

\section{Conclusions}

This discussion has focused on roles played by macrophages in resolution of acute inflammatory responses, in particular the removal of the inflammatory cells and debris and promotion of various forms of repair. However, it is important to note that structural cells of the tissues also play key roles in the resolution of inflammation and exhibit similar properties (up to and including ingestion of apoptotic cells) that were here described for macrophages. In addition, for reasons of limited cell numbers, while dendritic cells probably do not contribute to the bulk of clean-up in inflammation, their participation in the immunologic sequelae are of substantial importance. The arena for discussion of these 
concepts has been the lung, but while this is certainly a unique organ that has direct exposure to the outside environment, we suggest that the essential elements of macrophage participation in resolution of inflammation are equally applicable to other tissues and organs. Most importantly we propose that increasing our knowledge of normal resolution processes will have a direct future impact on our ability to deliberately enhance the resolution of chronic inflammation and thereby mediate an earlier return to normal tissue structure and function.

\section{Acknowledgments}

The author(s) disclosed receipt of the following financial support for the research, authorship, and/or publication of this article: This work was supported by HL68864, HL88138, and HL81151.

\section{References}

Aguilar LK, Aguilar-Cordova E, Cartwright J Jr, Belmont JW. Thymic nurse cells are sites of thymocyte apoptosis. J Immunol. 1994; 152:2645-651. [PubMed: 8144872]

Amarilyo G, Verbovetski I, Atallah M, Grau A, Wiser G, Gil O, Ben-Neriah Y, Mevorach D. Ic3bopsonized apoptotic cells mediate a distinct anti-inflammatory response and transcriptional nfkappab-dependent blockade. Eur J Immunol. 2010; 40:699-709. [PubMed: 20039295]

Aoshiba K, Nagai A. Senescence hypothesis for the pathogenetic mechanism of chronic obstructive pulmonary disease. Proc Am Thor Soc. 2009; 6:596-601.

Babic AM. Extracorporeal photopheresis: Lighting the way to immunomodulation. Am J Hematol. 2008; 83:589-91. [PubMed: 18335565]

Barton GM. A calculated response: Control of inflammation by the innate immune system. J Clin Invest. 2008; 118:413-20. [PubMed: 18246191]

Baumann I, Kolowos W, Voll RE, Manger B, Gaipl U, Neuhuber WL, Kirchner T, Kalden JR, Herrmann M. Impaired uptake of apoptotic cells into tingible body macrophages in germinal centers of patients with systemic lupus erythematosus. Arthritis Rheum. 2002; 46:191-201. [PubMed: 11817590]

Bellingan GJ, Caldwell H, Howie SE, Dransfield I, Haslett C. In vivo fate of the inflammatory macrophage during the resolution of inflammation: Inflammatory macrophages do not die locally, but emigrate to the draining lymph nodes. J Immunol. 1996; 157:2577-585. [PubMed: 8805660]

Bellingan GJ, Xu P, Cooksley H, Cauldwell H, Shock A, Bottoms S, Haslett C, Mutsaers SE, Laurent GJ. Adhesion molecule-dependent mechanisms regulate the rate of macrophage clearance during the resolution of peritoneal inflammation. J Exp Med. 2002; 196:1515-521. [PubMed: 12461086]

Botto M, Dell'Agnola C, Bygrave AE, Thompson EM, Cook HT, Petry F, Loos M, Pandolfi PP, Walport MJ. Homozygous c1q deficiency causes glomerulonephritis associated with multiple apoptotic bodies. Nat Gen. 1998; 19:56-9.

Bratton DL, Henson PM. Apoptotic cell recognition: Will the real phosphatidylserine receptor(s) please stand up? Curr Biol. 2008; 18:R76-9. [PubMed: 18211846]

Callahan MK, Williamson P, Schlegel RA. Surface expression of phosphatidylserine on macrophages is required for phagocytosis of apoptotic thymocytes. Cell Death Differ. 2000; 7:645-53. [PubMed: 10889509]

Cao C, Lawrence DA, Strickland DK, Zhang L. A specific role of integrin mac-1 in accelerated macrophage efflux to the lymphatics. Blood. 2005; 106:3234-241. [PubMed: 16002427]

Chiesa-Fuxench ZC, Gonzalez-Chavez J. Extracorporeal photopheresis: A review on the immunological aspects and clinical applications. P R Health Sci J. 2010; 29:337-47. [PubMed: 21261172]

Courtney PA, Crockard AD, Williamson K, Irvine AE, Kennedy RJ, Bell AL. Increased apoptotic peripheral blood neutrophils in systemic lupus erythematosus: Relations with disease activity, antibodies to double stranded DNA, and neutropenia. Ann Rheum Dis. 1999; 58:309-14. [PubMed: 10225817] 
Curtis JL, Freeman CM, Hogg JC. The immunopathogenesis of chronic obstructive pulmonary disease: Insights from recent research. Proc Am Thor Soc. 2007; 4:512-21.

Cvetanovic M, Ucker DS. Innate immune discrimination of apoptotic cells: Repression of proinflammatory macrophage transcription is coupled directly to specific recognition. J Immunol. 2004; 172:880-89. [PubMed: 14707059]

deCathelineau AM, Henson PM. The final step in programmed cell death: Phagocytes carry apoptotic cells to the grave. Essays Biochem. 2003; 39:105-17. [PubMed: 14585077]

Dockrell DH, Lee M, Lynch DH, Read RC. Immune-mediated phagocytosis and killing of streptococcus pneumoniae are associated with direct and bystander macrophage apoptosis. J Infect Dis. 2001; 184:713-22. [PubMed: 11517432]

Dockrell DH, Marriott HM, Prince LR, Ridger VC, Ince PG, Hellewell PG, Whyte MK. Alveolar macrophage apoptosis contributes to pneumococcal clearance in a resolving model of pulmonary infection. J Immunol. 2003; 171:5380-388. [PubMed: 14607941]

Douglas IS, Diaz, del Valle F, Winn RA, Voelkel NF. Beta-catenin in the fibroproliferative response to acute lung injury. Am J Respir Cell Mol Biol. 2006; 34:274-85. [PubMed: 16272459]

Erwig LP, Gordon S, Walsh GM, Rees AJ. Previous uptake of apoptotic neutrophils or ligation of integrin receptors downmodulates the ability of macrophages to ingest apoptotic neutrophils. Blood. 1999; 93:1406-412. [PubMed: 9949185]

Fadok VA, Bratton DL, Konowal A, Freed PW, Westcott JY, Henson PM. Macrophages that have ingested apoptotic cells in vitro inhibit proinflammatory cytokine production through autocrine/ paracrine mechanisms involving tgf-beta, pge2, and paf. J Clin Invest. 1998; 101:890-98. [PubMed: 9466984]

Fink SL, Cookson BT. Apoptosis, pyroptosis, and necrosis: Mechanistic description of dead and dying eukaryotic cells. Infect Immun. 2005; 73:1907-916. [PubMed: 15784530]

Frasch SC, Berry KZ, Fernandez-Boyanapalli R, Jin HS, Leslie C, Henson PM, Murphy RC, Bratton DL. Nadph oxidase-dependent generation of lysophosphatidylserine enhances clearance of activated and dying neutrophils via g2a. J Biol Chem. 2008; 283:33736-3749. [PubMed: 18824544]

Freire-de-Lima CG, Xiao YQ, Gardai SJ, Bratton DL, Schiemann WP, Henson PM. Apoptotic cells, through transforming growth factor-beta, coordinately induce anti-inflammatory and suppress proinflammatory eicosanoid and no synthesis in murine macrophages. J Biol Chem. 2006; 281:38376-8384. [PubMed: 17056601]

Gaipl US, Munoz LE, Grossmayer G, Lauber K, Franz S, Sarter K, Voll RE, Winkler T, Kuhn A, Kalden J, Kern P, Hermann M. Clearance deficiency and systemic lupus erythematosus (sle). J Autoimmun. 2007; 28:114-21. [PubMed: 17368845]

Gaipl US, Voll RE, Sheriff A, Franz S, Kalden JR, Herrmann M. Impaired clearance of dying cells in systemic lupus erythematosus. Autoimmun Rev. 2005; 4:189-94. [PubMed: 15893710]

Gardai SJ, Bratton DL, Ogden CA, Henson PM. Recognition ligands on apoptotic cells: A perspective. J Leuko Biol. 2006; 79:896-903. [PubMed: 16641135]

Golpon HA, Fadok VA, Taraseviciene-Stewart L, Scerbavicius R, Sauer C, Welte T, Henson PM, Voelkel NF. Life after corpse engulfment: Phagocytosis of apoptotic cells leads to vegf secretion and cell growth. Faseb J. 2004; 18:1716-718. [PubMed: 15345697]

Gordon S, Martinez FO. Alternative activation of macrophages: Mechanism and functions. Immun. 2010; 32:593-04.

Grimsley C, Ravichandran KS. Cues for apoptotic cell engulfment: Eat-me, don't eat-me and comeget-me signals. Trends Cell Biol. 2003; 13:648-56. [PubMed: 14624843]

Han J, Ulevitch RJ. Limiting inflammatory responses during activation of innate immunity. Nature Immunol. 2005; 6:1198-205. [PubMed: 16369559]

Hanayama R, Tanaka M, Miyasaka K, Aozasa K, Koike M, Uchiyama Y, Nagata S. Autoimmune disease and impaired uptake of apoptotic cells in mfg-e8-deficient mice. Science. 2004; 304:1147150. [PubMed: 15155946]

Heidari Y, Bygrave AE, Rigby RJ, Rose KL, Walport MJ, Cook HT, Vyse TJ, Botto M. Identification of chromosome intervals from 129 and c57bl/6 mouse strains linked to the development of systemic lupus erythematosus. Gen Immun. 2006; 7:592-99. 
Herrmann M, Voll RE, Zoller OM, Hagenhofer M, Ponner BB, Kalden JR. Impaired phagocytosis of apoptotic cell material by monocyte-derived macrophages from patients with systemic lupus erythematosus. Arthritis Rheum. 1998; 41:1241-250. [PubMed: 9663482]

Hodge S, Hodge G, Ahern J, Jersmann H, Holmes M, Reynolds PN. Smoking alters alveolar macrophage recognition and phagocytic ability: Implications in chronic obstructive pulmonary disease. Am J Resp Cell Mol Biol. 2007; 37:748-55.

Hodge S, Hodge G, Brozyna S, Jersmann H, Holmes M, Reynolds PN. Azithromycin increases phagocytosis of apoptotic bronchial epithelial cells by alveolar macrophages. Eur Respir J. 2006; 28:486-95. [PubMed: 16737992]

Hodge S, Hodge G, Holmes M, Reynolds PN. Increased airway epithelial and t-cell apoptosis in copd remains despite smoking cessation. Eur Respir J. 2006; 25:447-54. [PubMed: 15738287]

Hodge S, Hodge G, Scicchitano R, Reynolds PN, Holmes M. Alveolar macrophages from subjects with chronic obstructive pulmonary disease are deficient in their ability to phagocytose apoptotic airway epithelial cells. Immun Cell Biol. 2003; 81:289-96.

Hoffmann PR, deCathelineau AM, Ogden CA, Leverrier Y, Bratton DL, Daleke DL, Ridley AJ, Fadok VA, Henson PM. Phosphatidylserine (ps) induces ps receptor-mediated macropinocytosis and promotes clearance of apoptotic cells. J Cell Biol. 2001; 155:649-59. [PubMed: 11706053]

Hotamisligil GS. Inflammation and metabolic disorders. Nature. 2006; 444:860-67. [PubMed: 17167474]

Huynh ML, Fadok VA, Henson PM. Phosphatidylserine-dependent ingestion of apoptotic cells promotes tgf-beta1 secretion and the resolution of inflammation. J Clin Invest. 2002; 109:41-50. [PubMed: 11781349]

Ishimoto Y, Ohashi K, Mizuno K, Nakano T. Promotion of the uptake of ps liposomes and apoptotic cells by a product of growth arrest-specific gene, gas6. J Biochem. 2000; 127:411-17. [PubMed: 10731712]

Janssen WJ, Barthel L, Muldrow A, Oberley-Deegan RE, Kearns MT, Jakubzick C, Henson PM. Fas determines differential fates of resident and recruited macrophages during resolution of acute lung injury. Am J Resp Crit Care Med. 2011; 184:547-60. [PubMed: 21471090]

Janssen WJ, McPhillips KA, Dickinson MG, Linderman DJ, Morimoto K, Xiao YQ, Oldham KM, Vandivier RW, Henson PM, Gardai SJ. Surfactant proteins a and d suppress alveolar macrophage phagocytosis via interaction with sirp alpha. Am J Respir Crit Care Med. 2008; 178:158-67. [PubMed: 18420961]

Jensen ML, Honore C, Hummelshoj T, Hansen BE, Madsen HO, Garred P. Ficolin-2 recognizes DNA and participates in the clearance of dying host cells. Mol Immunol. 2007; 44:856-65. [PubMed: 16730064]

Kasahara Y, Tuder RM, Cool CD, Lynch DA, Flores SC, Voelkel NF. Endothelial cell death and decreased expression of vascular endothelial growth factor and vascular endothelial growth factor receptor 2 in emphysema. Am J Resp Crit Care Med. 2001; 163:737-44. [PubMed: 11254533]

Kim SJ, Gershov D, Ma X, Brot N, Elkon KB. Opsonization of apoptotic cells and its effect on macrophage and t cell immune responses. Ann N Y Acad Sci. 2003; 987:68-78. [PubMed: 12727625]

Kroemer G, Galluzzi L, Vandenabeele P, Abrams J, Alnemri ES, Baehrecke EH, Blagosklonny MV, El-Deiry WS, Golstein P, Green DR, Hengartner M, Knight RA, Kumar S, Lipton SA, Malorni W, Nuñez G, Peter ME, Tschopp J, Yuan J, Piacentini M, Zhivotovsky B, Melino G. Nomenclature Committee on Cell Death. Classification of cell death: Recommendations of the nomenclature committee on cell death 2009. Cell Death Differ. 2009; 16:3-11. [PubMed: 18846107]

Lee SH, Goswami S, Grudo A, Song LZ, Bandi V, Goodnight-White S, Green L, Hacken-Bitar J, Huh J, Bakaeen F, Coxson HO, Cogswell S, Storness-Bliss C, Corry DB, Kheradmand F. Antielastin auto-immunity in tobacco smoking-induced emphysema. Nat Med. 2007; 13:567-69. [PubMed: 17450149]

Ling S, Pi X, Holoshitz J. The rheumatoid arthritis shared epitope triggers innate immune signaling via cell surface calreticulin. J Immunol. 2007; 179:6359-367. [PubMed: 17947714]

Libby P. Inflammation in atherosclerosis. Nature. 2002; 420:868-74. [PubMed: 12490960] 
Luster AD, Alon R, von Andrian UH. Immune cell migration in inflammation: Present and future therapeutic targets. Nature Immunol. 2005; 6:1182-190. [PubMed: 16369557]

Marguet D, Luciani MF, Moynault A, Williamson P, Chimini G. Engulfment of apoptotic cells involves the redistribution of membrane phosphatidylserine on phagocyte and prey. Nat Cell Biol. 1999; 1:454-56. [PubMed: 10559991]

Matute-Bello G, Liles WC, Radella F II, Steinberg KP, Ruzinski JT, Jonas M, Chi EY, Hudson LD, Martin TR. Neutrophil apoptosis in the acute respiratory distress syndrome. Am J Respir Crit Care Med. 1997; 156:1969-977. [PubMed: 9412582]

Mechnikov, I. Ilya mechnikov Nobel lecture. 1908. (http://www.nobelprize.org/nobel_prizes/ medicine/laureates/1908/mechnikov-lecture.html)

Monks J, Rosner D, Geske FJ, Lehman L, Hanson L, Neville MC, Fadok VA. Epithelial cells as phagocytes: Apoptotic epithelial cells are engulfed by mammary alveolar epithelial cells and repress inflammatory mediator release. Cell Death Differ. 2005; 12:107-14. [PubMed: 15647754]

Morimoto K, Amano H, Sonoda F, Baba M, Senba M, Yoshimine H, Yamamoto H, Ii T, Oishi K, Nagatake T. Alveolar macrophages that phagocytose apoptotic neutrophils produce hepatocyte growth factor during bacterial pneumonia in mice. Am J Respir Cell Mol Biol. 2001; 24:608-15. [PubMed: 11350831]

Morimoto K, Janssen WJ, Fessler MB, McPhillips KA, Borges VM, Bowler RP, Xiao YQ, Kench JA, Henson PM, Vandivier RW. Lovastatin enhances clearance of apoptotic cells (efferocytosis) with implications for chronic obstructive pulmonary disease. J Immunol. 2006; 176:7657-665. [PubMed: 16751413]

Morimoto K, Janssen WJ, Fessler MB, Xiao YQ, McPhillips KA, Borges VM, Kench JA, Henson PM, Vandivier RW. Statins enhance clearance of apoptotic cells through modulation of rho-gtpases. Proc Am Thor Soc. 2006; 3:516-17.

Nathan C. Points of control in inflammation. Nature. 2002; 420:846-52. [PubMed: 12490957]

Okada H, Mak TW. Pathways of apoptotic and non-apoptotic death in tumour cells. Nature Rev. 2004; 4:592-603.

Palaniyar N, Nadesalingam J, Clark H, Shih MJ, Dodds AW, Reid KB. Nucleic acid is a novel ligand for innate, immune pattern recognition collectins surfactant proteins a and $\mathrm{d}$ and mannose-binding lectin. J Biol Chem. 2004; 279:32728-2736. [PubMed: 15145932]

Palaniyar N, Nadesalingam J, Reid KB. Innate immune collectins bind nucleic acids and enhance DNA clearance in vitro. Ann N Y Acad Sci. 2003; 1010:467-70. [PubMed: 15033771]

Peter C, Wesselborg S, Herrmann M, Lauber K. Dangerous attraction: Phagocyte recruitment and danger signals of apoptotic and necrotic cells. Apoptosis. 2010; 15:1007-028. [PubMed: 20157780]

Petrovski G, Berenyi E, Moe MC, Vajas A, Fesus L, Berta A, Facsko A. Clearance of dying arpe-19 cells by professional and nonprofessional phagocytes in vitro- implications for age-related macular degeneration (amd). Acta Ophthalmol. 2011; 89:e30-34. [PubMed: 21091941]

Ren Y, Tang J, Mok MY, Chan AW, Wu A, Lau CS. Increased apoptotic neutrophils and macrophages and impaired macrophage phagocytic clearance of apoptotic neutrophils in systemic lupus erythematosus. Arthritis Rheum. 2003; 48:2888-897. [PubMed: 14558095]

Richens TR, Linderman DJ, Horstmann SA, Lambert C, Xiao YQ, Keith RL, Boe DM, Morimoto K, Bowler RP, Day BJ, Janssen WJ, Henson PM, Vandivier RW. Cigarette smoke impairs clearance of apoptotic cells through oxidant-dependent activation of rhoa. Am J Respir Crit Care Med. 2009; 179:1011-021. [PubMed: 19264974]

Savill J. Apoptosis in resolution of inflammation. J Leuk Biol. 1997; 61:375-80.

Savill J, Dransfield I, Gregory C, Haslett C. A blast from the past: Clearance of apoptotic cells regulates immune responses. Nat Rev Immunol. 2002; 2:965-75. [PubMed: 12461569]

Savill J, Gregory C, Haslett C. Cell biology. Eat me or die. Science. 2003; 302:1516-517. [PubMed: 14645835]

Scott RS, McMahon EJ, Pop SM, Reap EA, Caricchio R, Cohen PL, Earp HS, Matsushima GK. Phagocytosis and clearance of apoptotic cells is mediated by mer. Nature. 2001; 411:207-11. [PubMed: 11346799] 
Serhan CN, Savill J. Resolution of inflammation: The beginning programs the end. Nature Immunol. 2005; 6:1191-197. [PubMed: 16369558]

Somersan S, Bhardwaj N. Tethering and tickling: A new role for the phosphatidylserine receptor. J Cell Biol. 2001; 155:501-04. [PubMed: 11706046]

Suzuki Y, Takeda M, Farbman AI. Supporting cells as phagocytes in the olfactory epithelium after bulbectomy. J Comp Neurol. 1996; 376:509-17. [PubMed: 8978466]

Svensson PA, Johnson MS, Ling C, Carlsson LM, Billig H, Carlsson B. Scavenger receptor class b type $\mathrm{i}$ in the rat ovary: Possible role in high density lipoprotein cholesterol uptake and in the recognition of apoptotic granulosa cells. Endocrinol. 1999; 140:2494-500.

Szodoray P, Papp G, Nakken B, Harangi M, Zeher M. The molecular and clinical rationale of extracorporeal photochemotherapy in autoimmune diseases, malignancies and transplantation. Autoimmun Rev. 2010; 9:459-64. [PubMed: 20044039]

Taraseviciene-Stewart L, Douglas IS, Nana-Sinkam PS, Lee JD, Tuder RM, Nicolls MR, Voelkel NF. Is alveolar destruction and emphysema in chronic obstructive pulmonary disease an immune disease? Proc Am Thor Soc. 2006; 3:687-90.

Tosello-Trampont AC, Nakada-Tsukui K, Ravichandran KS. Engulfment of apoptotic cells is negatively regulated by rho-mediated signaling. J Bio Chem. 2003; 278:49911-9919. [PubMed: 14514696]

Tracey KJ. Physiology and immunology of the cholinergic antiinflammatory pathway. J Clin Invest. 2007; 117:289-96. [PubMed: 17273548]

Vandivier RW, Henson PM, Douglas IS. Burying the dead: The impact of failed apoptotic cell removal (efferocytosis) on chronic inflammatory lung disease. Chest. 2006; 129:1673-682. [PubMed: 16778289]

Vandivier RW, Richens TR, Horstmann SA, deCathelineau AM, Ghosh M, Reynolds SD, Xiao YQ, Riches DW, Plumb J, Vachon E, Downey GP, Henson PM. Dysfunctional cystic fibrosis transmembrane conductance regulator inhibits phagocytosis of apoptotic cells with proinflammatory consequences. Am J Physiol. 2009; 297:L677-86.

Varin A, Mukhopadhyay S, Herbein G, Gordon S. Alternative activation of macrophages by il-4 impairs phagocytosis of pathogens but potentiates microbial-induced signalling and cytokine secretion. Blood. 2010; 115:353-62. [PubMed: 19880493] 


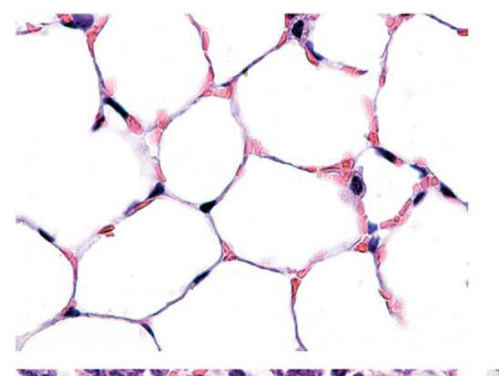
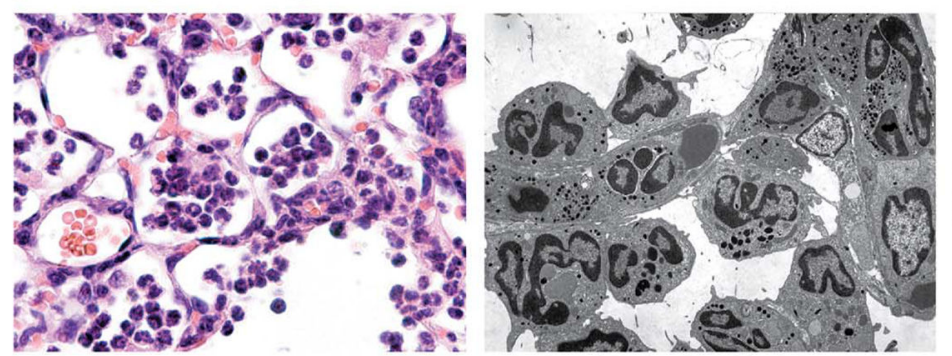

Neutrophil Phase

(Days 1-4)

Naive Lung
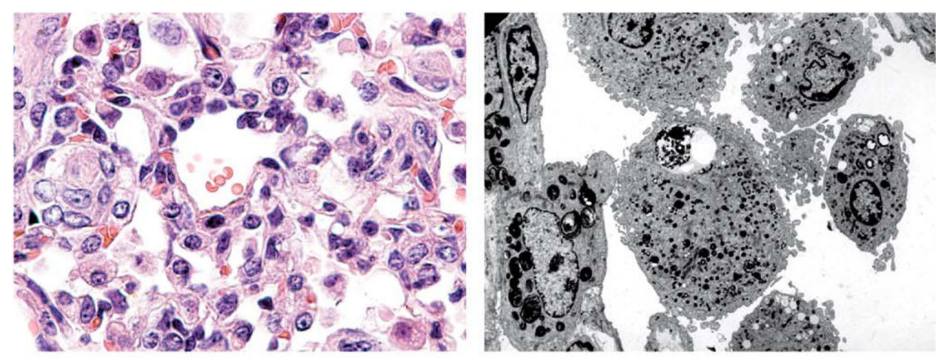

Macrophage Phase

(Days 4-9)

\section{Resolution}

(Days 9-12)

Figure 1.

Sequence of histological changes during an acute, self-limited inflammatory process. The left panels depict the murine lung parenchyma prior to injury (top), during the neutrophilic and macrophage phases (middle panels), and during resolution (bottom) following inflammation induced with bacterial lipopolysaccharide $(20 \mu \mathrm{g})$. The right panels depict equivalent electron micrographs of the neutrophil and macrophage stages. 


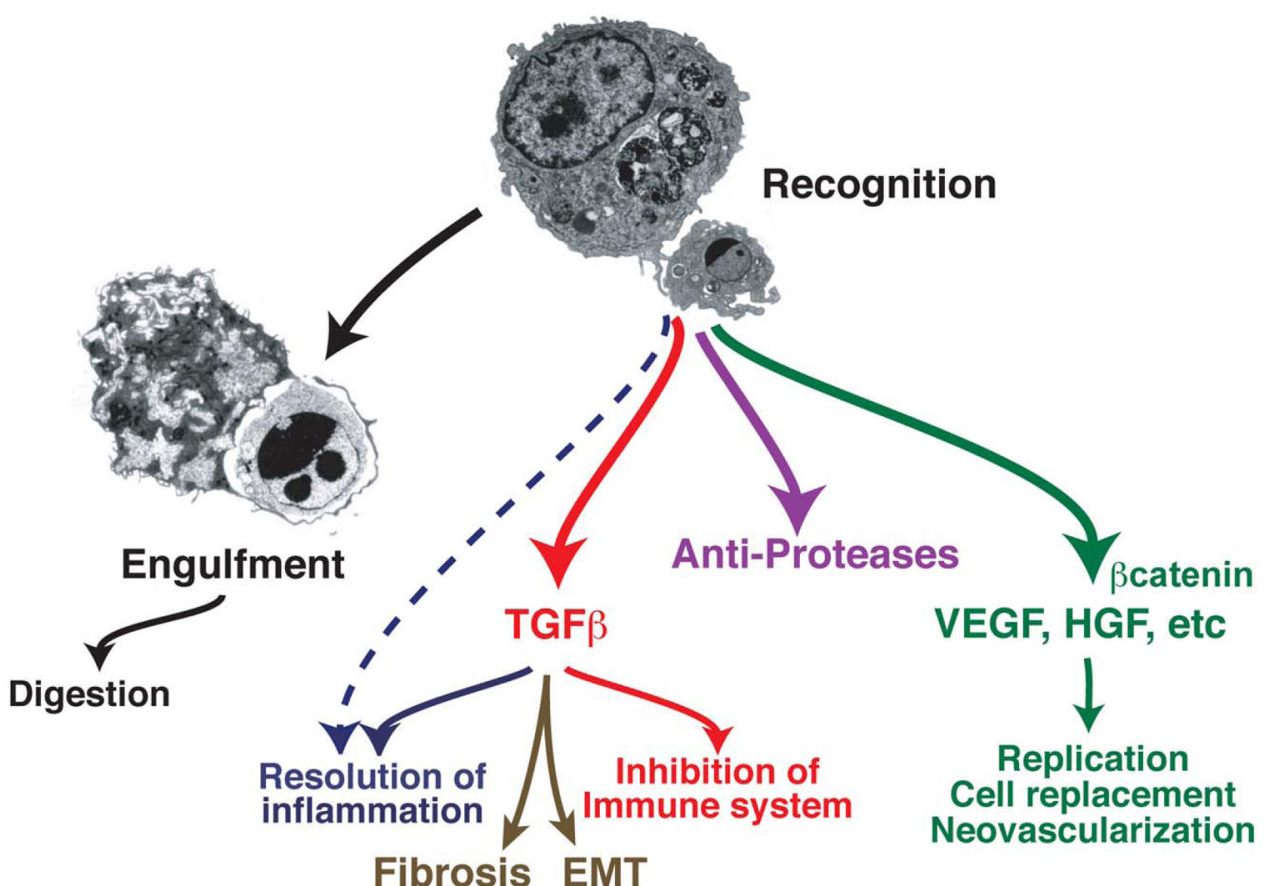

Figure 2.

Responses of macrophages to apoptotic cells that may participate in resolution of inflammation. 


\section{Table 1}

Apoptotic cell ligands and their phagocytic receptors.

\begin{tabular}{ll}
\hline Ligands & "Receptors" \\
\hline Phosphatidylserine (PS) & PS recognition structures (PSRS) \\
Calreticulin & LRP-1 (direct and via collection family members) \\
DNA/nucleoproteins & \\
Carbohydrate ligands & \\
Oxidized phospholipids & CD36 and other scavenger receptors \\
Lysophospholipids & G protein-coupled receptors \\
\hline
\end{tabular}

